\title{
Mengkaji Area Genangan Banjir Pasang Terhadap Penggunaan Lahan Pesisir Tahun 2020 Menggunakan Metode Geospasial di Kabupaten Pekalongan, Provinsi Jawa Tengah
}

\section{Maria Griselda*, Muhammad Helmi, Rikha Widiaratih, Anindya Wirasatriya dan Hariyadi}

Departemen Oseanografi, Fakultas Perikanan dan Ilmu Kelautan, Universitas Diponegoro

Jl. Prof. Soedarto, S.H., Tembalang, Semarang 50275

Email: *mariagriselda1311@gmail.com

\begin{abstract}
Abstrak
Perubahan iklim menyebabkan peningkatan suhu yang mempercepat laju muka air laut. Kenaikan muka air laut mengancam wilayah pesisir yang padat penduduk dan juga daratan rendah karena akan menyebabkan banjir rob. Salah satunya adalah pesisir Kabupaten Pekalongan. Banjir rob yang diakibatkan adanya kenaikan muka air laut dan penurunan muka tanah menyebabkan bertambahnya luasan genangan banjir rob di daratan. Penelitian ini melakukan pengolahan data untuk mengetahui karakteristik pasang surut bulan November 2020 dan laju kenaikan muka air laut, melakukan pengolahan data titik tinggi rupabumi untuk mengetahui elevasi muka tanah tahun 2020, melakukan pengolahan citra SAR Sentinel-1 untuk memetakan laju penurunan muka tanah serta mengkaji luas area genangan banjir rob pada penggunaan lahan dengan menggunakan pemodelan spasial genangan banjir pasang tahun 2020 berdasarkan data laju kenaikan muka air laut, ketinggian genangan, elevasi muka tanah, dan laju penurunan muka tanah. Metode yang digunakan pada penelitian ini untuk komponen pasang surut diolah menggunakan metode Least Square, laju kenaikan muka air laut dengan metode ROMS, laju penurunan muka tanah dengan metode DinSAR dan pemetaan genangan banjir rob dengan pemodelan geospasial. Hasil dari penelitian ini menunjukkan selisih nilai HHWL dan MSL pada bulan November 2020 adalah $42,11 \mathrm{~cm}$. Kenaikan muka air laut adalah 3,8 mm/tahun. Penurunan muka tanah rata-rata Kecamatan Wiradesa, Kecamatan Tirto, Kecamatan Siwalan dan Kecamatan Wonokerto adalah 20,27 cm/tahun, 20,58 cm/tahun, 21,63 cm/tahun dan 23,49 cm/ tahun. Luas daerah yang tergenang banjir rob pada bulan November 2020 adalah 783,99 hektar, tetapi dengan adanya tanggul menjadi 1,68 hektar.
\end{abstract}

Kata kunci: Banjir Rob, Kenaikan muka air laut, Penurunan muka tanah, Kabupaten Pekalongan

\begin{abstract}
Climate change causes temperature increase which accelerates sea level rise. Sea level rise threatens densely populated coastal areas and lowlands as it will cause tidal flood. One of the impacted area is the coastal area of Pekalongan Regency. Tidal flood in Pekalongan regency is worsened byland subsidence which causes an increase in the area of land inundation. In the present study we process the tide data to determine the tidal characteristics of November 2020 and trend trend of sea level rise, process topographical high point data to determine land level elevation in 2020, and anlyze SAR Sentinel-1 images to map the rate of land subsidence. Finally, we assess the area of tidal flood inundation using spatial modeling of tidal flood in 2020 based on the data of sea level rise, inundation height, land level elevation, and land subsidence rate. The method for extracting the tidal component was the Least Square method.Sea level rise used the ROMS method, land subsidence rate used the DinSAR method and tidal flood inundation mapping used geospatial modeling. The resultsshow that the difference between the HHWL and MSL values in November 2020 was 42,11 cm. The rate of sea level rise is 3,8 $\mathrm{mm} /$ year. The average land subsidence rate in Tirto District, Wiradesa District, Siwalan District and Wonokerto District is 20,27 cm/year, 20,58 cm/year, 21,63 cm/year and 23,49 cm/year, respectively. The area that was inundated by tidal floods in November 2020 was 783,99 hectares, but with the presence of embankments it became 1,68 hectares.
\end{abstract}

Keywords : Tidal flood, sea-level rise, land subsidence, Pekalongan Regency. 


\section{PENDAHULUAN}

Perubahan iklim menjadi ancaman terpenting bagi manusia di abad kedua puluh satu ini (Toan, 2014). Peristiwa ekstrim ini menyebabkan peningkatan suhu yang menyebabkan percepatan kenaikan muka air laut (Seenath et al., 2016). Diperkirakan laju kenaikan muka air laut global mencapai 1,1 $\mathrm{mm} /$ tahun selama abad ke-20 (Dangendorf et al., 2017). Kenaikan muka air laut mengancam wilayah pesisir yang padat penduduk dan juga daratan rendah (Khan et al., 2000; Qin and Lu, 2014). Hal itu yang menyebabkan adanya bencana pesisir yaitu banjir rob dan badai dahsyat (McClathey et al., 2014; Carvalho dan Wang, 2019). Banjir rob sendiri merupakan genangan air pada wilayah daratan pantai yang terjadi saat air laut pasang. Fenomena banjir rob di wilayah pesisir terjadi akibat beberapa faktor yaitu pasang surut air laut, kenaikan muka air laut dan penurunan muka tanah (Chandra dan Rima, 2013).

Banjir rob merupakan bencana yang sering terjadi di kota atau daerah di tepi pantai. Indonesia sendiri banjir rob sudah sering terjadi di beberapa kota besar seperti Jakarta Utara, Semarang dan juga Pekalongan (Chandra dan Rima, 2013; Kasbullah et al., 2014; Ramadhan et al., 2019). Banjir rob menggenangi bagian daratan pantai atau tempat yang lebih rendah dari muka air laut pasang tinggi ( $h i g h$ water level) (Wirasatriya, 2006). Kabupaten Pekalongan yang terletak di pesisir pulau Jawa merupakan satu dari sekian banyak wilayah di Indonesia yang masih terdampak daerahnya oleh banjir rob (Ramadhan et al., 2019). Sejak tahun 2002, Kabupaten Pekalongan menjadi langganan banjir rob dikarenakan Kabupaten Pekalongan mengalami dampak langsung oleh perubahan iklim yang terjadi. Adanya kenaikan muka air laut dan penurunan muka tanah memperluas serta memperdalam genangan rob di Kabupaten Pekalongan (Sauda et al., 2019; Moet et al., 2016). Banjir rob yang diikuti dengan penurunan muka tanah dan kenaikan muka air laut akan memperluas genangan (Marfai et al., 2008)

Pemerintah pusat di dalam RPJMN menjelaskan untuk mengurangi banjir rob dibangun tanggul laut dan bangunan pengaman di Pesisir Utara Pulau Jawa, termasuk pesisir Kabupaten Pekalongan (Bappenas, 2019). Pembangunan sudah dimulai sejak tahun 2017, dimana tanggul sepanjang 7,2 km dan setinggi 3 meter yang dibangun dari barat ke timur pesisir Pekalongan dan pada akhir tahun 2019 telah diresmikan oleh pemerintah pusat (Kartika dan Helmi, 2019).

Analisis spasial luas dan pola genangan banjir dari citra penginderaan jauh sangat penting untuk mitigasi dan pengelolaan banjir (Rahman dan Praveen, 2018). Berdasarkan penelitian sebelumnya, belum adanya penelitian yang memperhatikan penurunan muka tanah menggunakan data citra SAR Sentinel-1 dan kenaikan muka air laut menggunakan metode Regional Ocean Modelling System (ROMS) dalam pengolahannya, serta memperhatikan tanggul rencana yang terletak di pesisir Kabupaten Pekalongan. Maka peneltian "Mengkaji Area Genangan Banjir Pasang Terhadap Penggunaan Lahan Pesisir Pada Tahun 2020 Menggunakan Metode Geospasial di Kabupaten Pekalongan, Provinsi Jawa Tengah" perlu dilakukan sebagai salah satu raca untuk menanggulangi banjir pasang tersebut karena frekuensi Banjir rob akan terus meningkat dan luasan akan bertambah di masa mendatang (Salim dan Agus, 2018).

Karena itu diperlukan kajian lebih lanjut untuk mengurangi dampak banjir pasang terhadap penggunaan lahan untuk masa kini dan masa mendatang di Kabupaten Pekalongan (Kartika et al., 2019). Penelitian ini menggunakan metode geospasial dengan memperhatikan penurunan muka tanah dan kenaikan muka air laut akan menghasilkan peta prediksi genangan yang akan terjadi pada tahun 2020, di Kabupaten Pekalongan dan dampaknya terhadap penggunaan lahan di Kabupaten Pekalongan. 


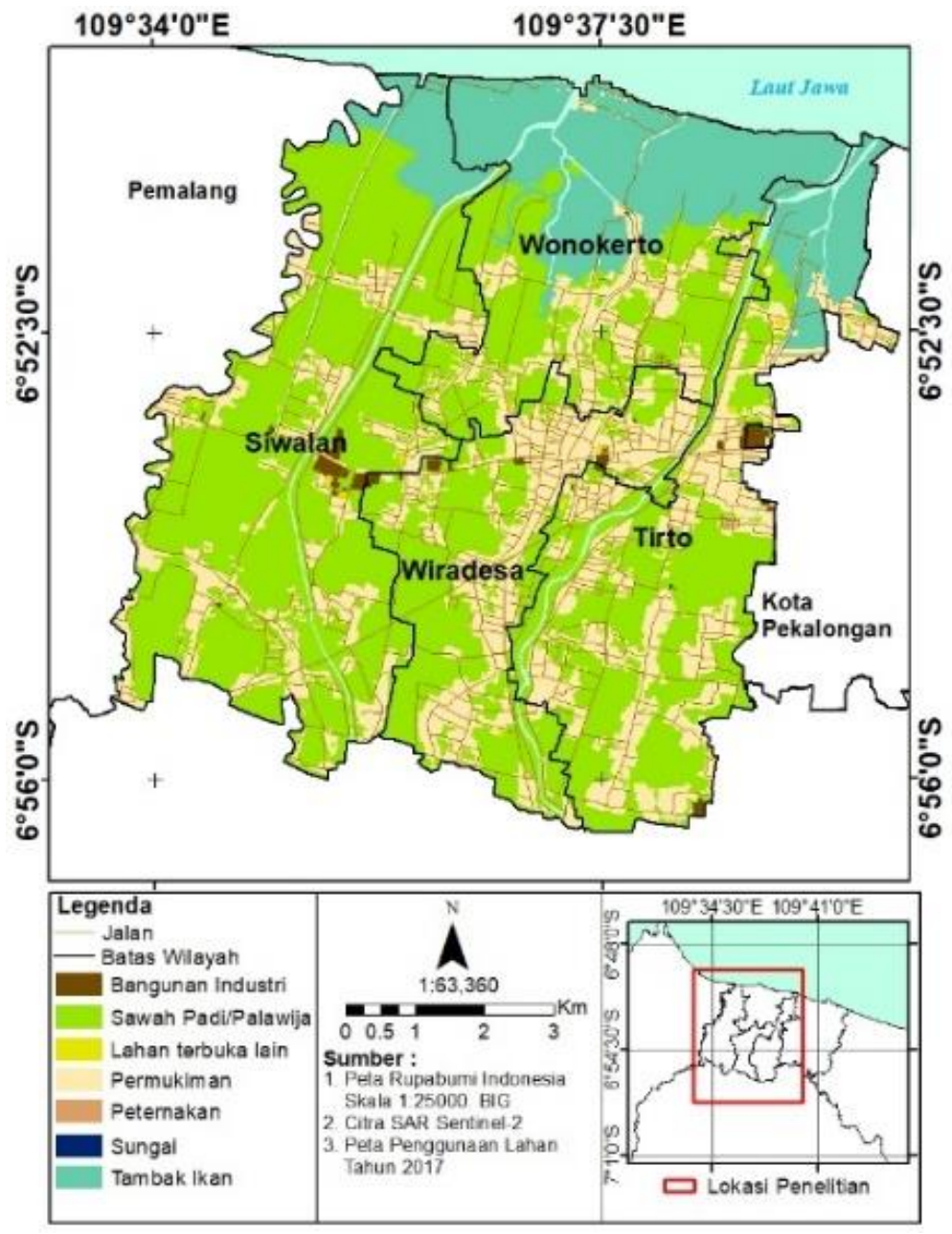

Gambar 1. Lokasi Penelitian

\section{MATERI DAN METODE PENELITIAN}

\section{Materi Penelitian}

Materi yang digunakan pada penelitian ini terbagi menjadi dua, yaitu data primer dan data sekunder. Data primer yaitu data pasang surut Kabupaten Pekalongan pengukuran BIG bulan November 2020, Citra SAR Sentinel-1 (Perekaman 17 Februari 2017, 29 September 2020, dan 7 Juli 2020), Data Sea Level Anomaly di Perairan Pekalongan tahun 1993-2018. Data sekunder yaitu peta Rupa Bumi Indonesia Kabupaten Pekalongan skala 1:25.000, peta jenis tanah tahun 2017, Peta penggunaan lahan tahun 2017, data titik tinggi hasil survei pemetaan topografi MercyCorps tahun 2019, data suvei batas genangan banjir rob terjauh.

\section{Metode Penelitian}

Metode penelitian ini menggunakan metode kuantitatif, yang dapat diartikan sebagai metode ilmiah/scientific karena telah memenuhi kaidah - kaidah ilmiah yaitu konkret/empiris, obyektif, terukur, rasional, dan sistematis. Metode ini disebut kuantitatif karena data penelitian yang digunakan berupa angka - angka dan analisis menggunakan statistik dan model (Sugiyono, 2009).

Penelitian ini terlebih dahulu dilakukan survei lapangan untuk mendapatkan di lokasi penelitian, kemudian pengumpulan data mengenai banjir rob, lalu akn dilakukan pengolahan data seperti pengolahan data pasang surut, pembuatan peta genangan banjir pasang. Disimpulkan bahwa sifat penelitian ini bersifat deskriptif karena metode yang digunakan untuk memberi gambaran mengenai 
masalah yang terjadi pada masa ini atau masalah yang sedang berlangsung. Peneltian deskriptif dilakukan untuk menjelaskan fakta, karakteritik serta hubungan kejadian yang diteliti (Nazir, 2015).

\section{Metode Penentuan Batas Genangan Banjir Rob Terjauh}

Metode yang digunakan untuk menentukan batas genangan banjir rob terjauh adalah dengan Indepth Interviewed. In-depth Interviewed adalah metode untuk memperoleh informasi untuk penelitian dengan tanya jawab secara tatap muka antara pewawancara dengan informan, dapat atau tanpa menggunakan pedoman wawancara (Boyce dan Neale., 2006). Metode wawancara ini digunakan untuk mendapatkan informasi mengenai titik terjauh genangan banjir rob. Titik yang digunakan sebagai lokasi penelitian sebanyak 36 titik akan di marking dengan menggunakan GPS untuk disimpan koordinat titik banjir rob tersebut.

\section{Metode Analisis Data}

\section{DTM}

InSAR adalah teknik yang digunakan untuk mengetahui informasi topografi dengan interferogram (Pinheiro et al., 2017). Data DSM Sentinel-1 yang sudah diolah menggunakan metode InSAR (Interferometric Synthetic Aperture Radar) akan dilakukan validasi dengan titik tinggi DTM survei lapangan tahun 2019 dengan cara diekstrak menggunakan extract values to point lalu akan diinterpolasi dengan metode Topo to Raster. Proses interpolasi dengan algorithma Inverse Distance Weighting (IDW)

\section{Penurunan Muka Tanah}

Data yang digunakan adalah citra pada bulan 17 Februari 2017 dan 07 Juli 2020. Menurut Ismullah (2004), citra SAR yang akan diolah secara interferometri, khususnya dari satelit sering disebut dengan citra kompleks atau SLC (Single Look Complex), yang mana dalam tiap pixelnya tersusun atas informasi amplitudo (a) dan phase $(\phi)$. Proses selanjutnya adalah Interferometry SAR Processing untuk membentuk pasangan citra interferogram. Proses ini berhubungan langsung dengan bentuk topografi wilayah studi namun masih terdapat unsur noise, deformasi dan atmosfer. Selanjutnya terdapat proses Differential Interferometry SAR (DInSAR) Processing. DinSAR dapat digunakan untuk mengetahui penurunan muka tanah secara teratur dalam waktu singkat dan datanya memiliki resolusi spasial yang tinggi (Simons et al., 2021). Lalu dilakukan perhitungan laju penurunan muka tanah setiap tahunnya dengan menggunakan raster calculator di perangkat lunak ArcGIS 10.3. Rumus perhitungan penurunan muka tanah tiap tahunnya sebagai berikut :

$$
\text { Velocity } \mathrm{PMT}=
$$

Nilai PMT $* 365$

Selang waktu akuisisi pasangan citra (dalam hari)

\section{Pasang Surut}

Data pengukuran Badan Informasi Geospasial berupa pasang surut pada bulan November tahun 2020 di stasiun Pekalongan. Menurut Mousavian et al (2012), analisis data yang digunakan untuk pasang surut adalah menggunakan analisis harmonik dengan metode kuadrat terkecil (Least Square), dimana analisa pasang surut yang dengan cara menguraikan gelombang pasang surut menjadi komponen-komponen harmonik dimana ketinggian muka air dikarenakan gelombang pasang surut yang merupakan hasil penjumlahan dari komponen-komponen gaya pembangkit pasang surut. Metode Least Square yang digunakan terdiri dari ERGTIDE, ERGRAM, ERGELV.

\section{Kenaikan Muka Air Laut}

Pengolahan kenaikan muka air laut dengan menggunakan metode ROMS. IndoSLR-V1.2 merupakan script untuk mendownload dan mengoreksi nilai muka air laut hasil proyeksi RCP4.5. Data 
olah didownload dari InaROMS (tides.big.go.id) dan CMEMS (https://marine.copernicus.eu/). Script ini akan memotong data proyeksi RCP45 InaROMS dan mengoreksinya dengan data observasi satelit.

Setelah nilai kenaikan muka air laut didapatkan akan dilakukan perhitungan menggunakan analisis trend linier menggunakan software Microsoft Excel 2013. Analisis trend linier digunakan untuk mendapatkan laju sea level rise.

\section{Model Geospasial Genangan Banjir Rob}

Menurut Marfai (2011) Proses pembentukan model spatial banjir rob dilakukan dengan menggunakan metode Spatial Analyst dengan tools Raster Calculator yang terdapat pada software ArcGIS 10.3. Persamaan yang digunakan pada tahap ini adalah :

$$
\mathrm{WD}=\operatorname{Con}(\operatorname{Con}([\mathrm{DEM}] \leq \text { Elevasi,Elevasi), } \operatorname{Con}([\mathrm{DEM}] \leq \text { Elevasi,Elevasi) }-[\mathrm{DEM}], 0)
$$

Dimana WD merupakan kedalaman air genangan banjir rob, DEM adalah data ketinggian tanah dan Elevasi merupakan pengurangan antara nilai HHWL dan MSL

\section{Model Geospasial Prediksi Genangan Banjir Rob}

Menurut Suhelmi (2012), penurunan muka tanah dan kenaikan muka air laut dianggap terjadi secara linier. Data HHWL dan MSL menjadi dasar dilakukannya perhitungan luas wilayah yang tergenang oleh banjir rob. Penetuan penyebaran genangan rob dapat dilakukan perhitungan menggunakan formula :

$$
\mathrm{DEMt}=\mathrm{DEM}-((\mathrm{Pt}-\mathrm{MSL} \mathrm{t})+\mathrm{St})
$$

Dimana DEMt adalah DEM daerah tergenang pada tahun t, DEM adalah DEM pengolahan titik tinggi, Pt adalah Pasang tertinggi, MSLt adalah Mean Sea Level pada tahun t dan St adalah Nilai subsiden pada tahun $\mathrm{t}$.

\section{HASIL DAN PEMBAHASAN}

Tabel 1. Hasil pengolahan pasang surut di Kabupaten Pekolangan bulan November 2020

\begin{tabular}{ccc}
\hline Konstituen & Amplitudo $(\mathrm{cm})$ & Beda Fasa \\
\hline $\mathrm{M}_{2}$ & 12.56 & -63.21 \\
$\mathrm{~S}_{2}$ & 8.71 & -53.67 \\
$\mathrm{~N}_{2}$ & 5.66 & 247.65 \\
$\mathrm{~K}_{2}$ & 3.62 & -23.09 \\
$\mathrm{~K}_{1}$ & 13.8 & 193.65 \\
$\mathrm{O}_{1}$ & 3.9 & 53.61 \\
$\mathrm{P}_{1}$ & 4.94 & 21.02 \\
$\mathrm{M}_{4}$ & 0.67 & 223.1 \\
$\mathrm{MS}_{4}$ & 1.01 & 249.8 \\
$\mathrm{~S}_{\mathrm{O}}$ & 161.24 & 180 \\
\hline
\end{tabular}

Hasil perhitungan Formzahl adalah 0.82 disimpulkan bahwa tipe pasang surut perairan Pekalongan adalah pasang campuran condong harian ganda. Hasil ini sama dengan dengan penelitian sebelumnya yang dilakukan oleh Syafrei et al (2020) dimana tipe pasang surutnya adalah campuran condong ke harian ganda. Tipe pasang surut campuran condong ke harian ganda yang dimaksud terjadi secara dua kali pasang dan dua kali surut dalam waktu sehari tetapi dengan periode yang berbeda. 


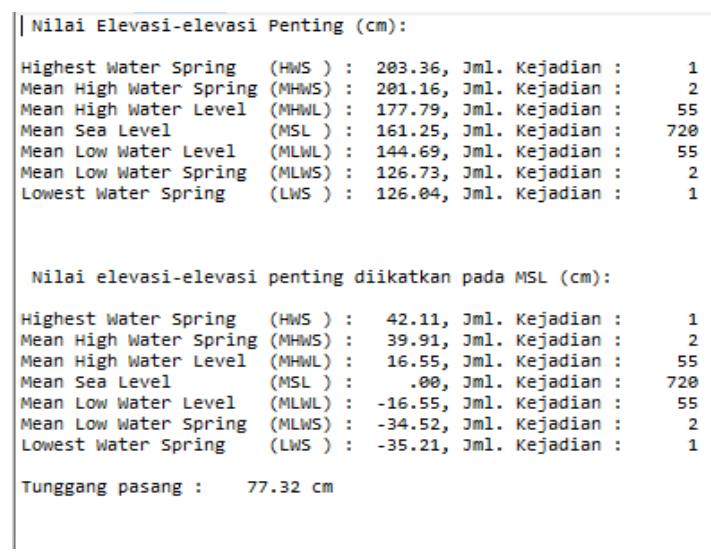

Gambar 2. Tampilan data pasang surut hasil pengolahan metode Least Square (Pengolahan Data, 2021)

Berdasarkan perhitungan menggunakan metode Least Square didapatkan nilai HHWL 203,36 cm dan MSL sebesar 161,25 cm. Genangan rob yang terjadi di Kabupaten Pekalongan berdasarkan selisih HHWL dan MSL setinggi 42,11 cm. Nilai selisih HHWL dan MSL akan digunakan sebagai data awal untuk model geospasial model genangan banjir rob. Kenaikan muka air laut di Perairan Kabupaten Pekalongan adalah $3,8 \mathrm{~mm} / \mathrm{tahun}$.

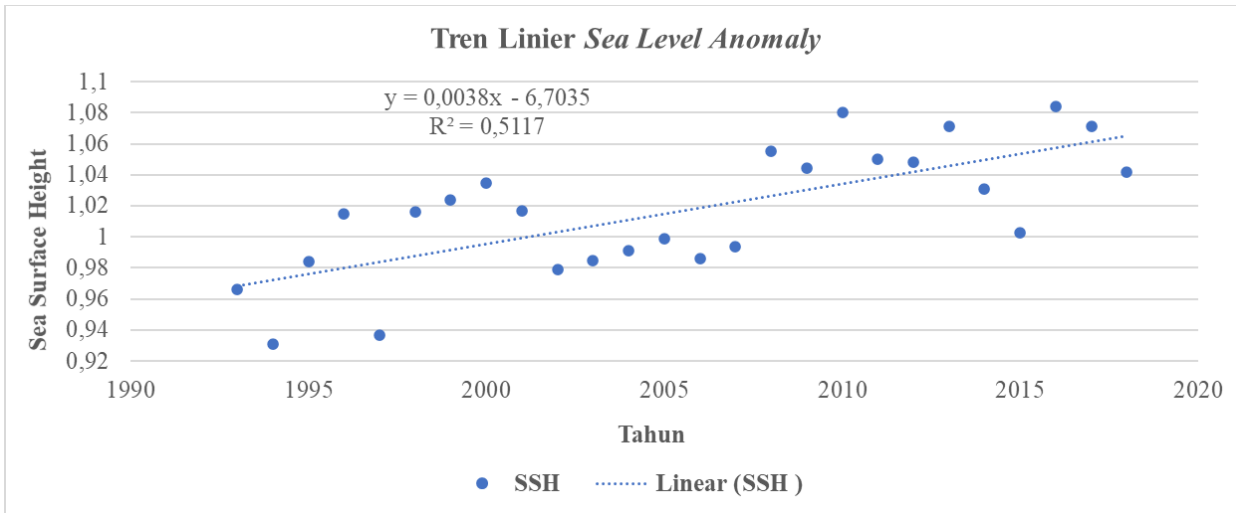

Gambar 3. Grafik Sea Level Anomaly di Perairan Kabupaten Pekalongan

Hasil pengolahan penurunan muka tanah dengan menggunakan metode DinSAR menunjukkan Kecamatan Wonokerto merupakan kecamatan dengan penurunan muka tanah tertinggi di Kabupaten Pekalongan sebesar 23,49 cm/tahun. Kecamatan Siwalan, Kecamatan Tirto dan Kecamatan Wiradesa, masing-masing mengalami penurunan muka tanah sebesar 21,63 cm/tahun, 20,58 cm/tahun, dan 20,27 $\mathrm{cm} / \mathrm{tahun}$. Hal ini diperkuat oleh Syafrei et al. (2020), dimana penurunan muka tanah di Pekalongan rata-rata mencapai 16,74 sampai $27,51 \mathrm{~cm}$ setiap tahunnya. Bila terus terjadi penurunan muka tanah di Kabupaten Pekalongan dapat mencapai 30 sampai $50 \mathrm{~cm}$ setiap tahunnya (Maharlika et al., 2020). Penurunan muka tanah di pesisir Kabupaten Pekalongan menjadi salah satu penyebab terjadinya genangan banjir rob disamping adanya kenaikan muka air laut yang terjadi setiap tahunnya. Faktor penurunan muka menyebabkan luasan wilayah tergenang semakin meningkat (Suhelmi, 2012). Penurunan muka tanah di Pesisir Kabupaten Pekalongan diakibatkan pula oleh jenis tanah yaitu alluvial. Hal ini diperkuat oleh Khoirunisa et al. (2015) dan Kasfari et al (2018) yang menyatakan jenis tanah alluvial yang merupakan lempung tanah muda dan mudah mengalami konsolidasi sehingga mengakibatkan tanah semakin turun. Besaran penurunan muka tanah ditunjukkan pada Gambar 4 berdasarkan nilai maksimal, minimal, dan rata-rata. 


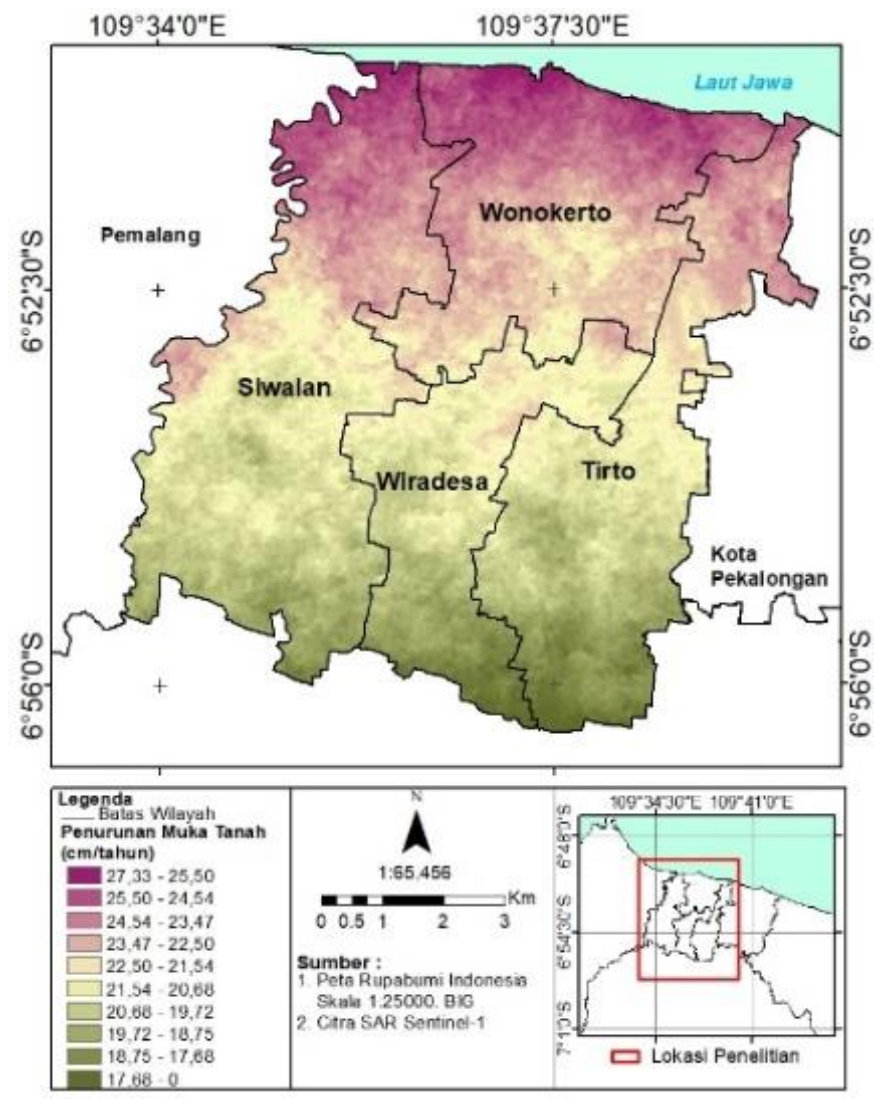

Gambar 4. Penurunan Muka Tanah tahun 2017-2020

Tabel 2. Penurunan Tanah Tiap Kecamatan

\begin{tabular}{clcccc}
\hline No & Kecamatan & Rata-Rata $(\mathbf{c m})$ & Maksimal $(\mathbf{c m})$ & Minimal $(\mathbf{c m})$ & Std. Dev \\
\hline 1 & Siwalan & 21,63 & 27,30 & 19,70 & 1,98 \\
2 & Wonokerto & 23,49 & 27,33 & 20,33 & 1,33 \\
3 & Wiradesa & 20,27 & 23,90 & 15,70 & 1,54 \\
4 & Tirto & 20,58 & 25,69 & 15,63 & 1,95 \\
\hline
\end{tabular}

Hasil elevasi ketinggian muka tanah pada gambar 5 menunjukkan ketinggian di pesisir Kabupaten Pekalongan adalah 0 - 7,66 meter. Menurut Fariz dan Nur (2017) penelitian sebelumnya menyatakan ketinggian deaerah yang tergenang banjir pada tahun 2017 yaitu Kabupaten Pekalongan terdiri dari 4 kecamatan yaitu Kecamatan Tirto , Kecamatan Siwalan, Kecamatan Wonokerto dan Kecamatan Wiradesa memiliki ketinggian antara 0 meter hingga 22 meter. Perbedaan hasil penelitian dikarenakan adanya perbedaan nilai koherensi pada pasangan citra SAR Sentinel-1 pada gelombang Cband tidak dapat memantulkan gelombang dengan sempurna di daerah vegetasi rapat dan wilayah berair. Adanya perbedaan elevasi paling rendah pada pemukiman karena tidak ada perubahan dan meyebabkan menghalangi gelombang C-band sehingga nilai koherensi lebih besar (Sunu et al., 2019). Perbedaan hasil ketinggian tanah juga dapat diakibatkan karena adanya faktor penurunan tanah sehingga tanah semakin turun setiap tahunnya. 


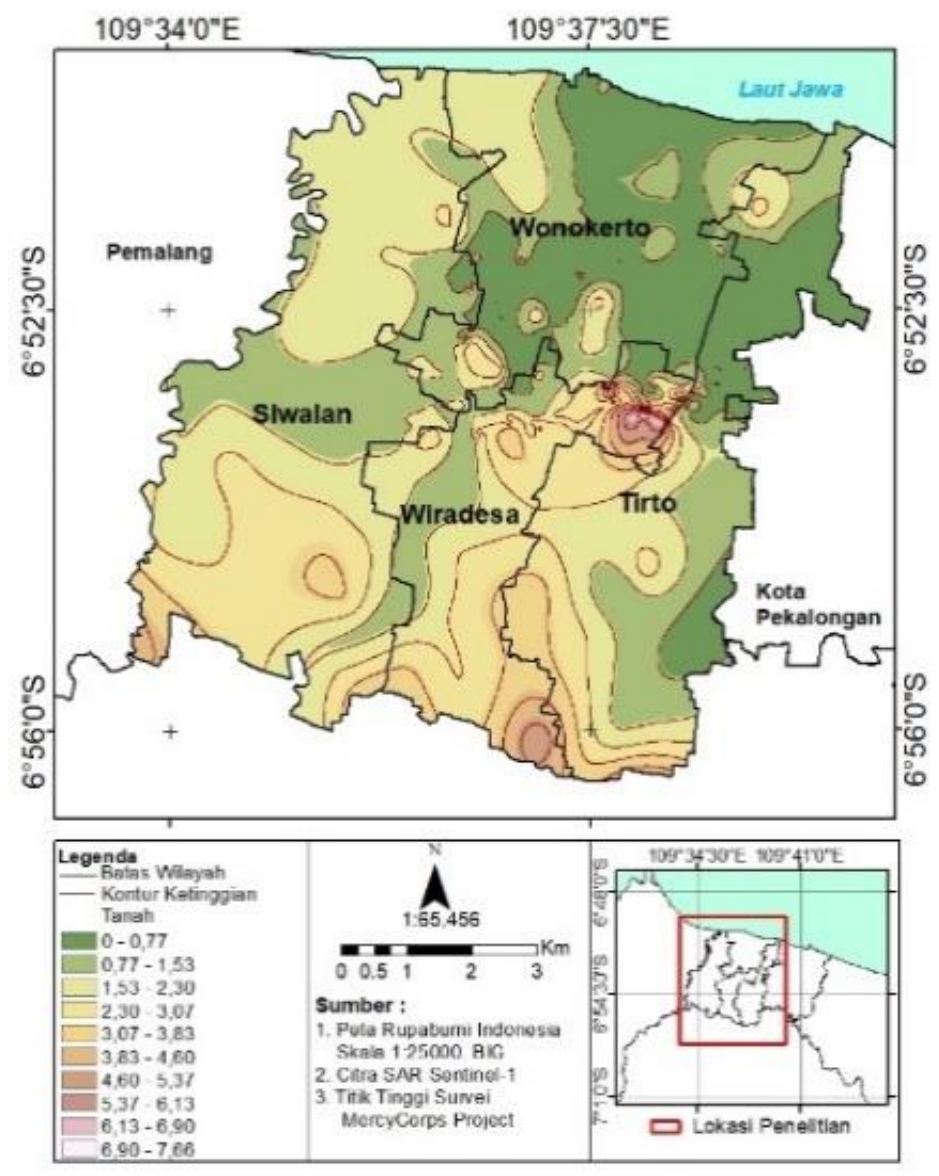

Gambar 5. Peta Ketinggian Tanah Pesisir Kabupaten Pekalongan

Hasil titik survei genangan banjir rob pada bulan November 2020 didapatkan 12 titik yang masih tergenang, ditunjukkan pada Tabel 3.

Tabel 3. Lokasi Survei Banjir Rob di Kabupaten Pekalongan

\begin{tabular}{ccccc}
\hline No & Latitude & Longitude & Kelurahan & Guna Lahan \\
\hline 1 & $-6.846514^{\circ}$ & $109.632919^{\circ}$ & Wonokerto Kulon & Sawah Padi/Palawija \\
2 & $-6.849127^{\circ}$ & $109.625527^{\circ}$ & Wonokerto Kulon & Sawah Padi/Palawija \\
3 & $-6.844735^{\circ}$ & $109.623183^{\circ}$ & Wonokerto Kulon & Sawah Padi/Palawija \\
4 & $-6.842625^{\circ}$ & $109.619398^{\circ}$ & Semut & Sawah Padi/Palawija \\
5 & $-6.843707^{\circ}$ & $109.621192^{\circ}$ & Semut & Sawah Padi/Palawija \\
6 & $-6.843552^{\circ}$ & $109.626015^{\circ}$ & Wonokerto Kulon & Sawah Padi/Palawija \\
7 & $-6.867393^{\circ}$ & $109.643505^{\circ}$ & Pecakaran & Pemukiman \\
8 & $-6.874252^{\circ}$ & $109.622443^{\circ}$ & Bebel & Pemukiman \\
9 & $-6.866480^{\circ}$ & $109.638028^{\circ}$ & Pecakaran & Pemukiman \\
10 & $-6.886358^{\circ}$ & $109.640829^{\circ}$ & Karangjompo & Pemukiman \\
11 & $-6.878081^{\circ}$ & $109.646991^{\circ}$ & Tegaldowo & Pemukiman \\
12 & $-6.886213^{\circ}$ & $109.647262^{\circ}$ & Karangjompo & Pemukiman \\
\hline
\end{tabular}

Hasil pengolahan yang didapatkan berupa selisih HHWL dan MSL sebesar 42,11 cm pada bulan November 2020, model genangan banjir ditunjukkan pada gambar 6 . 


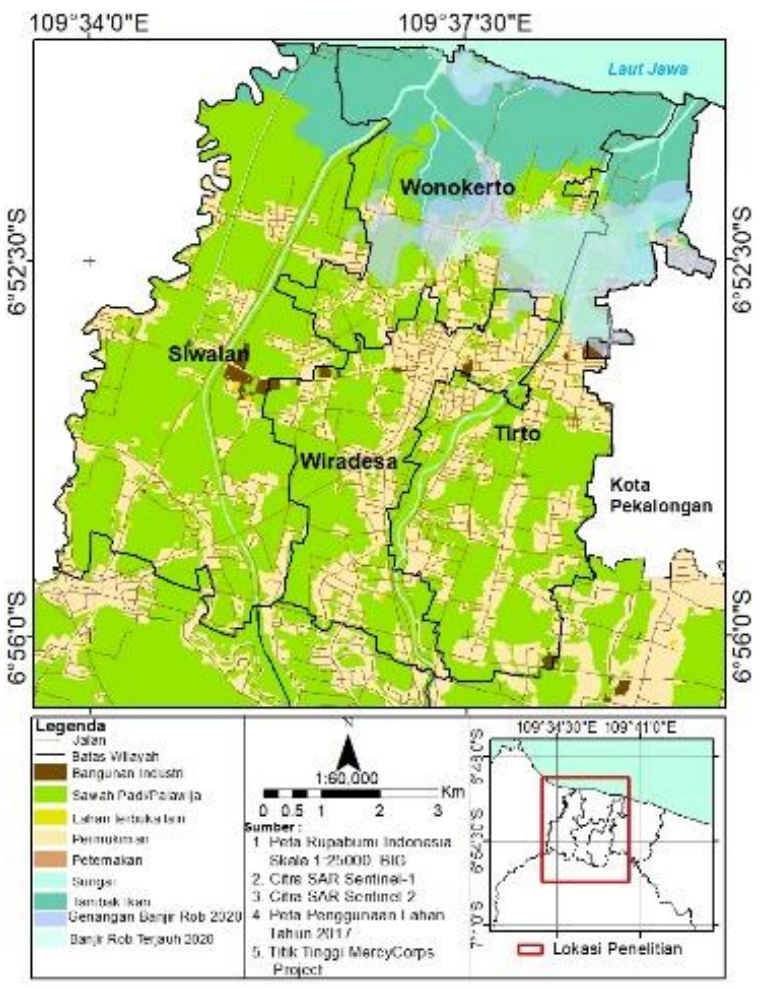

Gambar 6. Peta Genangan Banjir Pasang di Pesisir Kabupaten Pekalongan Tahun 2020 Tanpa Adanya Tanggul

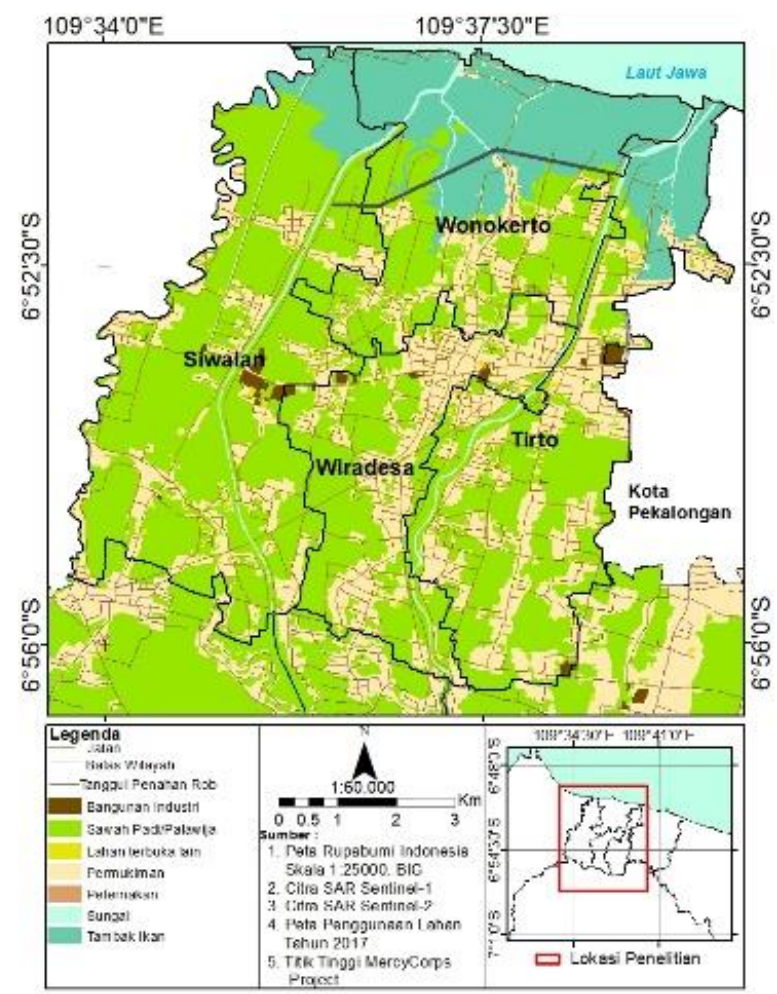

Gambar 7. Peta Genangan Banjir Pasang di Pesisir Kabupaten Pekalongan Tahun 2020 dengan Adanya Tanggul 
Berdasarkan pemodelan spasial genangan banjir rob pada bulan November 2020, daerah yang seharusnya mengalami banjir rob sebesar 783,99 hektar dimana Kecamatan Wonokerto menjadi wilayah dengan genangan terluas yaitu 439,23 hektar dan Kecamatan Siwalan menjadi wilayah yang paling sedikit tergenang yaitu seluas 7,26 hektar. Terjadinya genangan banjir rob dikarenakan topografi yang lebih rendah dibandingkan dengan pasang tetinggi yang terjadi setiap bulannya. Pasang surut terjadi dikarenakan adanya perbedaan gaya gravitasi dimana terjadinya pergantian posisi antara bulan dan matahari yang relative pada satu titik di permukaan bumi. Pasang tertinggi terjadi saat purnama ketika bulan, matahari dan bumi berada dalam satu garis lurus. Lahan yang seharusnya terdampak pada tahun 2020 sebesar 783,99. Tetapi dengan adanya tanggul setinggi 3 meter, luasan genangan banjir rob berkurang sangat besar, dimana banjir rob hanya menggenangi 1,68 hektar di dua kecamatan yaitu Kecamatan Tirto seluas 1,54 hektar dan Kecamatan Wiradesa seluas 0,13 hektar.

Tabel 3. Luas Genangan Banjir Rob Yang Seharusnya Terjadi Tiap Kecamatan tahun 2020

\begin{tabular}{|c|c|c|c|}
\hline Kecamatan & Lahan Terdampak & Luas (Ha) & Total (Ha) \\
\hline \multirow{2}{*}{ Siwalan } & Sawah Padi / Palawija & 6.18 & \multirow{2}{*}{7.26} \\
\hline & Pemukiman & 1.08 & \\
\hline \multirow{5}{*}{ Tirto } & Banguman Industri ... & 0.67 & \multirow{5}{*}{309.11} \\
\hline & Sawah Padi / Palawija & 108.37 & \\
\hline & Pemukiman & 112.87 & \\
\hline & Tambak Ikan & 84.30 & \\
\hline & Lahan Terbuka Lain & 2.90 & \\
\hline \multirow{4}{*}{ Wiradesa } & Bangunan Industri & 5.81 & \multirow{4}{*}{28.39} \\
\hline & Sawah Padi / Palawija & 14.14 & \\
\hline & Pemukiman & 8.36 & \\
\hline & Lahan Terbuka Lain & 0.07 & \\
\hline \multirow{5}{*}{ Wonokerto } & Bangunan Industri & 0.41 & \multirow{5}{*}{439.23} \\
\hline & Sawah Padi / Palawija & 205.26 & \\
\hline & Pemukiman & 114.20 & \\
\hline & Tambak Ikan & 117.83 & \\
\hline & Lahan Terbuka Lain & 1.53 & \\
\hline \multicolumn{3}{|c|}{ Total Luas Lahan Terdampak (Ha) } & 783.99 \\
\hline
\end{tabular}

Tabel 4. Total luas wilayah yang tergenang oleh banjir rob di Kabupaten Pekalongan tahun 2020 dengan adanya tanggul

\begin{tabular}{clcc}
\hline Kecamatan & Lahan Terdampak & Luas $($ Ha) & \multirow{2}{*}{ Total (Ha) } \\
\hline \multirow{2}{*}{ Tirto } & Pemukiman & 1.21 & \multirow{2}{*}{1.55} \\
\cline { 2 - 3 } & Sawah padi/Palawija & 0.34 & \\
\hline \multirow{2}{*}{ Wiradesa } & Pemukiman & 0.12 & \multirow{2}{*}{0.13} \\
\cline { 2 - 3 } & Sawah padi/palawija & 0.01 & \\
\hline \multicolumn{2}{r}{ Total Luas Lahan Terdampak (Ha) } & $\mathbf{1 . 6 8}$ \\
\hline
\end{tabular}

Penurunan muka tanah merupakan pengaruh terbesar terjadinya banjir rob dibandingkan dengan kenaikan muka air laut karena laju penurunan muka tanah yang terus terjadi di Kecamatan Wonokerto, Kecamatan Siwalan, Kecamatan Tirto dan juga Kecamatan Wiradesa dengan rata-rata masing-masing kecamatan sebesar 23,49 cm/tahun, 21,63 cm/tahun, 20,58 cm/tahun dan 20,27 $\mathrm{cm} / \mathrm{tahun}$ dan laju kenaikan muka air laut hanya $3,8 \mathrm{~mm} / \mathrm{tahun}$. Hal ini diperkuat oleh Shidik et al. (2019) yang menyatakan adanya korelasi antara penurunan muka tanah yang berlangsung terus menurus menyebabkan ketinggian topografi suatu wilayah menjadi semakin rendah. 
Adanya tanggul di Pesisir Kabupaten Pekalongan mampu mengurangi luasan genangan namun tanggul rencana setinggi 3 meter dilihat melalui pengolahan pemodelan spasial, efektifitas tanggul pada tahun 2020 mencapai 99,79\%. Banjir rob yang akan terjadi di Kabupaten Pekalongan merupakan dampak dari penurunan muka tanah yang terus terjadi.

\section{KESIMPULAN}

Berdasarkan pengolahan data pasang surut pada bulan November 2020 didapatkan tipe pasang surut di Kabupaten Pekalongan adalah campuran condong ke harian ganda dengan nilai Formzahl (F) sebesar 0,82 dan laju kenaikan muka air laut sebesar 3,8 mm/tahun. Hasil pengolahan menggunakan metode DinSAR didapatkan laju penurunan muka tanah sebesar 15,63 cm/tahun hingga 27,33 cm/tahun. Berdasarkan pengolahan data DEM didapatkan elevasi ketinggian muka tanah yaitu $0-7,66$ meter. Hasil pemodelan spasial genangan banjir rob tahun 2020 seluas 783,99 hektar .

\section{DAFTAR PUSTAKA}

Bappenas. 2019. Rencana Pembangunan Jangka Menengah Nasional (RPJMN) 2020-2024. Kementrian Perencanaan Pembangunan Nasional.

Boyce, C., dan Neale, P. 2006. Conducting In-Depth Interview: A Guide for Designing and Conducting In-Depth Interviews for Evaluation Input. Pathfinder International Tool Series, Monitoring and Evaluation-2.

Carvalho, K.S., dan S. Wang. 2019. Characterizing the Indian Ocean Sea Level Changes and Potential Coastal Flooding Impacts Under Global Warming. Journal of Hydrology. 569 : 373-386.

Chandra, Rangga., dan Rima Dewi Supriharjo. 2013. Mitigasi Bencana Banjir Rob di Jakarta Utara. Jurnal Teknik Pomits. 2(1): 2337-3539.

Dangendorf, S., Marcos, M., Woppelmann., G., Conrad, C.P., Frederikse, dan T., Riva, R. 2017. Reassessment of 20th Century Global Mean Sea Level Rise. Proc. Natl. Acad. Sci. Unit. States Am : 114 (23): 5946-5951.

Fariz, Trida Ridho., dan Nur Rokhayati. 2017. Konversi DSM Menjadi DTM Menggunakan Filter Berbasis Kelerengan untuk Pemetaan Genangan Banjir Rob di Kecamatan Tirto. Seminar Nasional ke-3 Pengelolaan Pesisir dan DAS.

Ismullah, I. 2004. Pengolahan Fasa untuk Mendapatkan Model Tinggi Permukaan Dijital (DEM) pada Radar Aperture Sintetik Interferometri (InSAR) Data Satelit. Sains \& Tek. 36A(1) : 11-32.

Kartika, F. D. S., dan Helmi, M. 2019. Meta-Analysis of Community's Adaptation Pattern with Tidal Flood in Pekalongan City, Central Java, Indonesia. In E3S Web of Conferences. (125) : 09001. EDP Sciences.

Kasbullah, Achmad Arief., dan Muhammad Aris Marfai. 2007. Pemodelan Spasial Genangan Banjir Rob dan Penilaian Potensi Kerugian Pada Lahan Pertanian Sawah Pada Studi Kasus Wilayah Pesisir Kabupaten Pekalongan, Jawa Tengah. Geoedukasi. 3(2)

Kasfari, Roy., Bambang Darmo Yuwono., Moehammad Awaluddin. 2018. Pengamatan Penurunan Muka Tanah Kota Semarang Tahun 2017. Jurnal Geodesi Undip. 7(1). 
Khan, T.M.A., Singh, O.P., dan Rahman, M.S., 2000. Recent Sea Level and Sea Surface Temperature Trends Along the Bangladesh Coast in Relation to the Frequency of Intense Cyclones. Mar. Geod. 23, 103-116.

Khoirunisa, Risty., Bambang Darmo Yuwono., dan Arwan Putra Wijaya. 2015. Analisis Penurunan Muka Tanah Kota Semarang Tahun 2015 Menggunakan Perangkat Lunak Gamit 10.5. Jurnal Geodesi Undip. 4(4)

Maharlika, Andrea Ramadhani., Sudharto Prawata Hadi., Kismartini., dan Lenty Hoya. 2020. Tidal Flooding and Coastal Adaptation Responses in Pekalongan City. ICENIS.

Marfai, MA., dan King, L. 2008. Tidal Inundation Mapping under Enchanced Land Subsidence in Semarang Central Java Indonesia. Environmental Geology., 55 : 1507-1518.

Marfai, Muh Aris., Nursakti Adhi Pratomoatmojo., Taufi k Hidayatullah., Anang Widhi Nirwansyah., dan Muammar Gomareuzzaman. 2011. Model Kerentanan Wilayah Pesisir Berdasarkan Perubahan Garis Pantai dan Banjir Pasang. Yogyakarta : Percetakan Pohon Cahaya.

McClatchey, John., Robert Devoy., David Woolf., Barbara Bremmer., Neil James. 2014. Climate Change and Adaptation in The Coastal Areas of Europe's Northern Periphery Region. Ocean \& Coastal Management 94. 9-21

Moe, Idham Riyando., Shuichi Kure., Nurul Fajar Januriyadi., Mohammad Farid., Keiko Udo, So Kazama, Shunichi Koshimura. 2016. Effect of Land Subsidence on Flood Inundation in Jakarta, Indonesia. Global Environment Engineering Research. 24 (5): 283-289

Mousavian, R., dan Mashhadi Hossainali. 2012. Detection of Main Tidal Frequencies Using Least Squares Harmonic Estimation Method. Journal of Geodetic Science. 2(3) : 224 -233.

Nazir, Moh. 2011. Metode Penelitian. Jakarta: PT. Ghalia Indonesia.

Pinheiro, Muriel., Andreas Reigber., dan and Alberto Moreira. 2017. Large-baseline InSAR for Precise Topographic Mapping: a Framework for TanDEM-X Large-Baseline Data. Adv. Radio Sci. 15: 231-241

Qin, X.S., dan Lu, Y. 2014. Study of Climate Change Impact on Floof Frequencies: a Combined weather Generator and Hydrological modeling approach. J. Hydrometeorol. 15 : 1205-1219

Ramadhan, Febrian., Eva Banowati., dan Hariyanto. 2019. Pengaruh Rob Terhadap Perubahan Pendapatan Petani Tambak di Kecamatan Tirto Kabupaten Pekalongan. Geo-Image, 8(1).

Salim, Muh.Afif., dan Agus Bambang Siswanto. 2019. Penanganan Banjir dan ROB di Wilayah Pekalongan.

Sauda, Rida Hilyati., Arief Laila Nugraha., dan Hania'ah. 2019. Kajian Pemetaan Kerentanan Banjir Rob di Kabupaten Pekalongan. Jurnal Geodesi Undip, 8(1)

Seenath, Avidesh., Matthew Wilson., Keith Miller. 2016. Hydrodynamic versus GIS modelling for Coastal Flood Vulnerability sasessment: Which is better for guiding coastal management?. Ocean \& Coastal Management 120, 99-109.

Shidik, Agus Nur., Dwi Utari., dan Meliana Atmika. 2019. Analisis Faktor Penyebab Banjir Rob dan Strategi Penanggulangannya dengan PEmbangunan Breakwater di Wilayah Semarang Utara, Jawa Tengah, Indonesi. Prosiding Seminar Nasional Kebumian Ke-12. 
Simons, Bailey S., dan Jessica M. Wempen. 2021. Quantifying Relationships Between Subsidence and Longwall Face Advance Using DInSAR. International Journal of Mining Science and Technology 31, 91-94.

Sugiyono. 2009. Metode Kuantitatif, Kualitatif dan R\&D. Cetakan ke 8. Bandung : Alfabeta

Suhelmi, I.R. 2012. Kajian Dampak Land Subsidence Terhadap Peningkatan Luas Genangan Rob di Kota Semarang. GEOMATIKA, 18(1).

Sunu, Handaru Aryo., Bambang Darmo Yuwono., dan Andri Suprayogo. 2019. Analisis Ketelitian DSM Kota Semarang dengan Metode InSAR Menggunakan Citra Sentinel-1. Jurnal Geodesi Undip, 8(3).

Wirasatriya, Anindya. 2006. Kajian Kenaikan Muka Laut Sebagai Landasan Penanggulangan Rob Di Pesisir Kabupaten Semarang. Jurnal Pasir Laut, 1(2) : 31-42 